\title{
Tools of the trade: studying actin in zebrafish
}

\author{
Clyde Savio Pinto $^{1}$ (D) Masanori Mishima ${ }^{1,2} \cdot$ Karuna Sampath $^{1,2,3}$
}

Accepted: 6 October 2020 / Published online: 23 October 2020

(c) The Author(s) 2020

\begin{abstract}
Actin is a conserved cytoskeletal protein with essential functions. Here, we review the state-of-the-art reagents, tools and methods used to probe actin biology and functions in zebrafish embryo and larvae. We also discuss specific cell types and tissues where the study of actin in zebrafish has provided new insights into its functions.
\end{abstract}

Keywords Zebrafish $\cdot$ Actin $\cdot$ Cytoskeleton $\cdot$ Imaging $\cdot$ Inhibitors

\section{Introduction}

Actin is a cytoskeletal protein that is highly abundant inside animal cells. It is an asymmetric molecule including the site of the nucleotide-binding cleft and polymerises to form a double helical filament (dos Remedios et al. 2003). Polymerisation occurs in a polarised fashion, with a higher rate of monomer addition at the barbed end than the pointed end and generates flexible filaments (Pollard 1986). Filaments also age with change of nucleotide state from ATP to ADP (Pollard et al. 2000). The filaments are organised into higher order structures and can generate force, provide stiffness and serve as tracks for the movement of cargo.

There are three classes of actin-the alpha, beta and gamma actin-in mammals. The alpha actins are found in muscle cells and are of three types: skeletal, cardiac and smooth. All three types of muscle actins are present in zebrafish, with approximately $99 \%$ identity to the corresponding human proteins. The other mammalian actins are found predominantly in non-muscle cells and are called cytoplasmic actins (Rubenstein 1990).

Clyde Savio Pinto

Clyde.pinto@warwick.ac.uk

Karuna Sampath

K.Sampath@warwick.ac.uk

1 Division of Biomedical Sciences, Warwick Medical School, University of Warwick, Coventry CV4 7AL, UK

2 Centre for Mechanochemical Cell Biology, University of Warwick, Coventry CV4 7AL, UK

3 Center for Early Life, Warwick Medical School, University of Warwick, Coventry CV4 7AL, UK
In zebrafish, there are two cytoplasmic actins, namely actin B1 (actb1) and actin B2 (actb2), based upon a uniprot analysis (UniProt 2019). They differ by only one amino acid at the position 3, with glutamic acid in B1 and aspartic acid residue in B2 (Fig. 1). B1 and B2 share significant homology with human actins beta and gamma, with only 3-5 amino acid changes. These include differences in the variable $\mathrm{N}$-terminus region of actin which also distinguishes Beta from Gamma human actin. How these differences modify the properties of actin has not yet been studied, but considering the sequence similarity of the zebrafish actins to both Beta and Gamma actins, it is unclear if the zebrafish cytoplasmic actins can be classified under either of these two classes or whether they represent evolutionary intermediates.

Post-translational modifications can modify the repertoire of a protein's functions (Wang et al. 2014). Actin is also post-translationally modified resulting in alterations of its properties (Varland et al. 2019). In mammalian systems, the Beta isoform of actin is post-translationally arginylated in vivo, however, this modification does not occur on the gamma isoform (Kashina 2006). Also, mammalian actin is acetylated (Varland et al. 2019). Whether zebrafish actins are post-translationally modified, and what types of modifications on actin are present is currently unknown. Additionally, the molecular properties of zebrafish actins have not been studied.

Recently, Scheid et al. (2017) purified zebrafish skeletal muscle actins and demonstrated their filament forming and myosin interacting capacities in vitro. Despite a lack of data regarding the biochemical properties of zebrafish cytoplasmic actins, considering the fact that they share almost complete sequence homology with the well-studied mammalian 


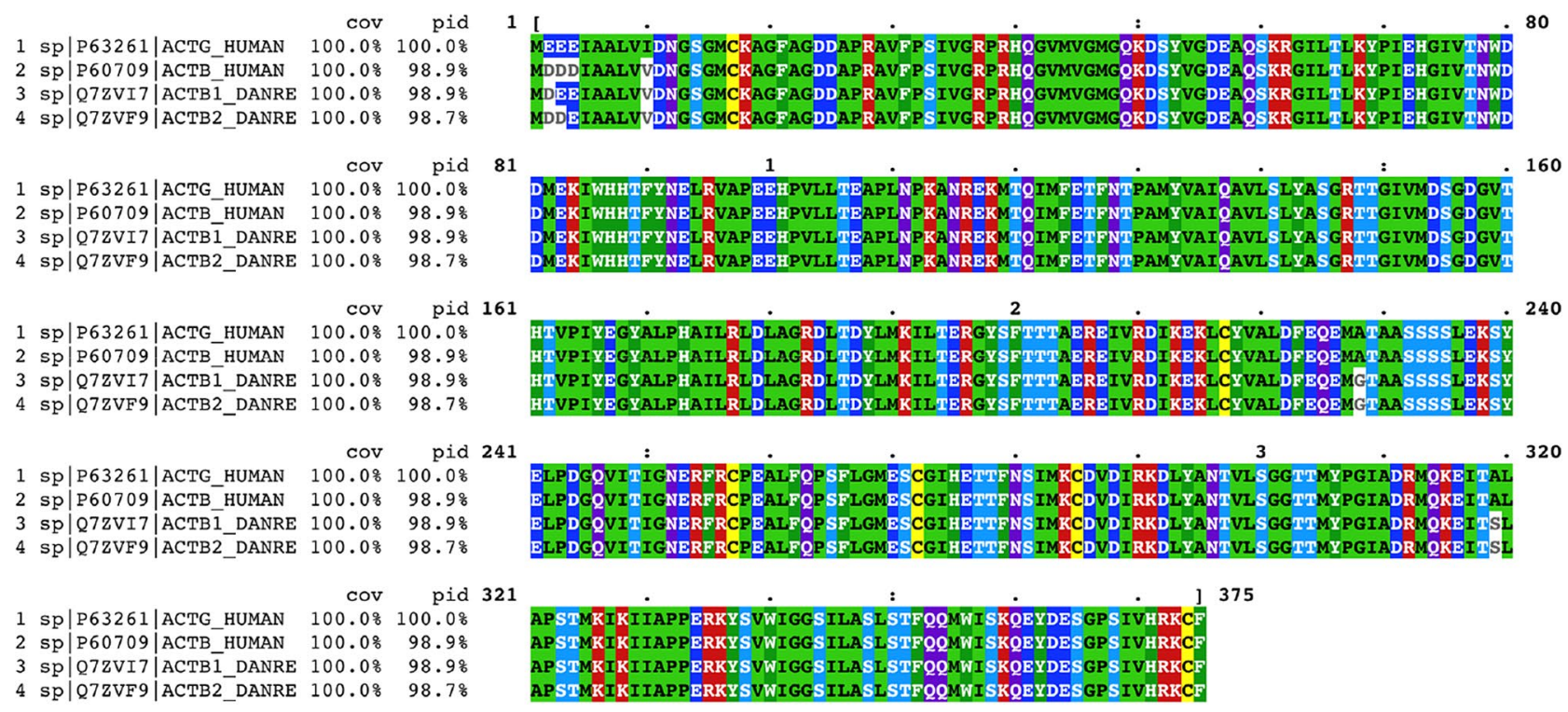

Fig. 1 Clustal omega based comparison of the human and zebrafish (Danio rerio) cytoplasmic actins. The sequences were obtained from uniprot (UniProt 2019), aligned using clustal omega (Sievers et al.

actins, it is likely that their properties and structure are similar to the mammalian proteins. Since actins are an essential part of the cytoskeleton that generate physical forces and mediate cell shape changes, they have been imaged in zebrafish embryos and larvae, and actins properties have been modified in many ways.

Zebrafish are widely known to possess several features that are advantageous for the study of various aspects of biology especially cell and developmental biology as well as disease pathology. Some of these advantages are that they have a high fecundity, transparent embryos, rapid development, susceptibility to genetic, chemical and physical manipulations and offer relatively easy high-resolution imaging in a live vertebrate organism (Vacaru et al. 2014; Torraca and Mostowy 2018; Meyers 2018). These significant benefits make zebrafish attractive for the study of actin and its regulation in various cells and tissues, in an in vivo vertebrate setting. In this review, we provide an overview of the tools and techniques that can be used to visualise and alter zebrafish actins.

\section{The visualisation of actin in cells}

\section{Phalloidin staining}

Phalloidin originally isolated from Amanita phalloides (death cap mushroom) has a high affinity for F-actin. It is a bicyclic peptide and is not membrane permeable (Wulf et al. 1979). It is used either in live or fixed cells. In live cells or
2011), and viewed using Mview (Brown et al. 1998). cov is the percent coverage and pid is the percent identity relative to the reference sequence which is ACTG_HUMAN

in vitro, phalloidin can be used to stabilize actin filaments by preventing depolymerisation (Melak et al. 2017; Coluccio and Tilney 1984). This stabilisation can be used either to study the effects of stabilizing actin in a given context or to preserve actin in techniques in which actin is otherwise prone to disruption such as electron microscopy. However, as phalloidin does not penetrate membranes, it needs to be delivered into cells e.g. by microinjection (Planques et al. 1991), or used as a membrane permeable form called phalloidin-oleate (Dutta and Kumar Sinha 2015).

In electron microscopy, fixation approaches popularised by Svitkina (2016) cells in which actin is to be preserved are first unroofed to remove their membrane using a buffer containing Triton X-100 and phalloidin, sometimes also containing polyethylene glycol (PEG). The phalloidin and PEG are thought to protect and stabilize the actin cytoskeleton during fixation and downstream processing. This is followed by fixation with glutaraldehyde, uranyl acetate and platinum replica plating for TEM or staining by the OTOTO method for SEM (Pinto et al. 2019; Svitkina 2016). Previous studies reported the reliable use of this method for fish cells in culture (Svitkina et al. 1997), and recently, this approach has also been used on $2 \mathrm{dpf}$ zebrafish larvae, followed by SEM to examine the actin microridge in zebrafish (Pinto et al. 2019).

The most widespread use of phalloidin is in the form of fluorescent derivatives used for the staining of F-actin in fixed cells, making it a quintessential part of the actin imaging toolkit. Phalloidin staining is typically performed on paraformaldehyde (PFA) fixed samples without methanol upgradation, as methanol adversely affects the preservation 
and detection of actin (Melak et al. 2017). It can be used in one of two ways. For cells in culture and for surface cells in zebrafish, the fixative itself is sufficient for permeabilising cells and no detergent is required. Higher concentrations of phalloidin might be required for this technique and normally a dilution of 1:40 (using an approximately $66 \mu \mathrm{M}$ stock) over 3-4 $\mathrm{h}$ is sufficient for good labelling of zebrafish peridermal actin (Pinto et al. 2019).

For staining the epidermis as well as deeper tissue, however, detergent-based permeabilization is routinely employed normally using Triton X-100 and phalloidin dilutions from 1:40 to $1: 400$ as appropriate (Pinto et al. 2019). Staining times need to be modified to ensure that the tissue of interest is stained. For older animals or internal tissues, it is also possible to either dissect the tissue of interest or section the sample by means of a vibratome, microtome or cryostat (Sidhaye et al. 2016). It should be noted, however, that both fixation as well as the expression of live imaging probes have the potential to generate artefacts. Expression of high levels of molecules such as LifeAct in cells can stabilize actin filaments (Flores et al. 2019). On the other hand, while 4\% PFA in PBS is routinely used for a number of staining methods, it might be inadequate for actin preservation under some conditions and more optimal fixation methods employing buffers that contain, for instance, EGTA and magnesium (e.g. PEM) may be required (Pereira et al. 2019; Wheatley and Wang 1998; Leyton-Puig et al. 2016; Heuser and Kirschner 1980). These factors should be kept in mind and optimised during experimentation and analysis to obtain reliable results.

\section{LifeAct and Utrophin-CH domain}

LifeAct and Utrophin-CH domain have been the most widely used probes for the live imaging of actin in zebrafish. LifeAct is a small 17 amino acid actin-binding peptide from the Abp140 protein of Saccharomyces cerevisiae with the amino acid sequence 'MGVADLIKKFESISKEE' (Riedl et al. 2008). The small size facilitates cloning as a codon optimised LifeAct sequence can be included directly on a long primer for fusion to a fluorescent protein or tag of interest. It has been shown to reliably bind to F-actin in various contexts and so is the go to probe for imaging actin dynamics in vivo, however, it might also bind G-actin (Melak et al. 2017). Care should be exercised when using LifeAct as at high concentrations it has been demonstrated to alter actin dynamics in vivo as well as can have an overall impact on the cytoskeleton and biology of the cell (Flores et al. 2019).

The calponin homology domain of human Utrophin (Burkel et al. 2007) is also widely used to label F-actin. This domain does not bind to G-actin, and in this sense, is considered superior to LifeAct for the purpose of imaging only F-actin (Winder et al. 1995). It is relatively large in size including the first 261 amino acids of human UTROPHIN. Zebrafish lines for the utrophinCH domain exist and are widely used (Behrndt et al. 2012).

\section{SiR-actin}

This actin probe consists of silicon-rhodamine ( $\mathrm{SiR})$ conjugated desbromo-desmethyl-jasplakinolide (Lukinavicius et al. 2014). The key advantage of SiR-Actin is that it is cell permeable and photostable (Lukinavicius et al. 2014) and, therefore, in the context of the external surface of zebrafish, SiR-Actin facilitates live imaging of endogenous actin. For instance, it has been used to observe actin in the retina of zebrafish (Matejcic et al. 2018). SiR and SiR-Actin emit fluorescence in the far-red wavelength (Lukinavicius et al. 2013, 2014). Its photostability make it a useful tool to probe Actin through super resolution microscopy techniques such as STED (Lukinavicius et al. 2014).

\section{Actin chromobody}

Nanobodies from Camelidae can be genetically encoded with fluorescent fusion tags and expressed in cells. Such 'chromobodies' against actin have been generated and can serve as powerful tools to image and study actin structures in vivo (Panza et al. 2015). Actin chromobodies have been used in zebrafish and stable lines have been generated. This can serve as an excellent genetically encoded tool to study live actin dynamics in vivo and can mark both $F$ and $G$ actin (Panza et al. 2015). However, this tool has not yet been widely exploited, and can potentially provide new insights into actin dynamics in zebrafish.

\section{Injection of labelled actins}

One of the significant strengths of zebrafish, especially when studying early development is the ability to inject protein/ RNA/DNA into the 1 cell stage embryo or in one or more cells at the 16 cells stage embryo. At these stages, the cells are sufficiently large, allowing microinjection with relative ease under a stereo microscope (Gupta and Sonawane 2020; Rosen et al. 2009). It is also possible to inject the yolk cell at later time points to image and manipulate components and study the contribution of this cell to developmental processes.

Injecting protein or RNA or DNA each have their advantages or disadvantages. Protein injections allow the study of these molecules from the timepoint of injection till their degradation. For instance, the injection of LifeActRFP protein will allow the immediate detection of F-actin in vivo. RNA encoding such actin imaging or manipulating molecules, however, will only express post maternal zygotic transition, but this should allow the imaging of these 
molecules for a longer time duration till mRNA and protein are degraded. mRNAs with special UTR's can also allow tissue-specific expression such as with the nanos 3'UTR that is not degraded in the germ line and so allows the imaging or manipulation of PGC's. Finally, plasmid DNA can also be used for transient transgenesis, either with or without transposable elements. However, plasmid DNA expression is typically mosaic, patchy, and expression is clonal, which might be advantageous in some contexts, but may not be useful if widespread expression is desired. The use of transposable elements and transposase results in the integration of the sequence of interest into the zebrafish genome and long-term expression (Kawakami 2007). Plasmids can be generated with promoters of interest such as the Actb promoter or the CMV promoter, that express robustly in multiple cell types.

While bulky tags such as GFP are known to alter actin's polymerisation properties especially when fused to the $\mathrm{N}$-terminus of actin (Nagasaki et al. 2017), rhodamine or other small fluorescent dyes can be used to label actin decreasing the negative effects of bulky groups and allowing the visualisation of actin in vivo. Typically, human platelet actin or actin from muscle sources of various animals such as rabbits is used for these purposes. One of the biggest advantages of labelled actin is that it allows the direct assay of actin dynamics either by means of speckle microscopy or by other methods such as FRAP (Waterman-Storer et al. 1998). The labelled actins can be introduced into zebrafish embryos via microinjection (Cheng et al. 2004). Recently, a robust new method for the expression of homogenous functional actins from recombinant yeast has been developed (Hatano et al. 2018, 2020). Actin expressed, purified and labelled in this way has been tested in zebrafish embryos (Hatano et al. 2018). However, as yet mammalian but not zebrafish actins have been used in such studies.

\section{C-terminus of Moesin}

The C-terminus of the actin-binding protein, Moesin, has been used in zebrafish to image actin in vivo, through a transgenic line that allows the visualisation of actin filaments and actin dynamics during oogenesis and early development (Nukada et al. 2015).

\section{Modulation of the actin cytoskeleton by means of inhibitors}

\section{Cytochalasin}

Cytochalasins act by capping the barbed end of actin and preventing the addition as well as the disassociation of actin monomers at this end (Brown and Spudich 1981; MacLeanFletcher and Pollard 1980). A wide range of cytochalasins are available, which are soluble in DMSO and can be diluted into the E3, Danieau buffers or fish water prior to use with fish embryos. Recently, a photoactivable or caged form of cytochalasin D that allows the spatio-temporal control of cytochalasin targeting has also been described (Latorre et al. 2018).

\section{Latrunculins}

Latrunculins are small molecule inhibitors that affect the actin cytoskeleton in multiple ways including the sequestration of monomers and increasing the rate of filament breakdown (Fujiwara et al. 2018). They have been very widely used in zebrafish. Latrunculins are soluble in DMSO and can be stored as $1 \mathrm{mM}$ stocks at $-20^{\circ} \mathrm{C}$, and can be diluted before use. A $2 \mu \mathrm{M}$ working solution of latrunculin A for 20 min treatment is a good starting point (Raman et al. 2016). It should be noted that all treatments need to be titrated and optimised to facilitate the investigation of the processes under study as different treatment regimens might be toxic or lethal to the animal or to particular cell types.

\section{Blebbistatin}

Myosin 2 activity being the primary driver of acto-myosin contractility, inhibition of its activity is widely employed in zebrafish biology. Blebbistatin is an inhibitor that binds to myosin in the $\mathrm{ADP}+\mathrm{Pi}$ state and reduces the rate of release of $\mathrm{Pi}$, in this state myosin has a low affinity for actin (Kovacs et al. 2004). Blebbistatin is inactivated by light of wavelengths below $488 \mathrm{~nm}$, which can be used to reactivate myosin activity, but should also be considered when live imaging GFP and similar fluorophores in the presence of blebbistatin (Sakamoto et al. 2005). Blebbistatin is soluble in DMSO and can be stored as a $100 \mathrm{mM}$ stock solution at $-20{ }^{\circ} \mathrm{C}$. A suitable starting concentration is $10 \mu \mathrm{M}$, for a duration of $1.5 \mathrm{~h}$ (Raman et al. 2016).

\section{Arp2/3 complex inhibitors}

One of the key regulators of actin structure is the Arp2/3 complex. It is a seven subunit complex that serves as a nucleator of new actin filaments (Pollard et al. 2000). It is the key nucleator of branched actin filaments that are found in actin structures such as lamellipodia, growth cones as well as endocytic actin patches (Korobova and Svitkina 2008; Wu et al. 2012; Galletta et al. 2008). Specific inhibitors of the Arp2/3 complex were published by the Pollard group in 2009 (Nolen et al. 2009). One of the most commonly used Arp2/3 complex inhibitors is CK-666 which works by stabilizing the inactive state of the complex. Another, drug CK-869 works by destabilizing the active state of the Arp2-Arp3 dimer (Hetrick et al. 2013). These two molecules are soluble in 
DMSO and can be stored at $-20^{\circ} \mathrm{C}$. They are often used with their inactive drug controls, CK-689 for CK-666 and CK-312 for CK-869. A good starting concentration to try is $100 \mu \mathrm{M}$ for $1 \mathrm{~h}$ (Pinto et al. 2019).

\section{SMIFH2}

Another critical nucleator of actin is the group of proteins known as formins. They not only nucleate actin but also elongate actin filaments and have wide importance in multiple actin structures that might be made of branched or unbranched filaments (Breitsprecher and Goode 2013). While there are 15 formin proteins in mammals a common structural element in formins is the formin homology 2 domain (Schonichen and Geyer 2010) [An Interpro taxonomy search for formin, $\mathrm{FH} 2$ domain superfamily shows 55 proteins in Danio rerio and 71 in Homo sapiens (Mitchell et al. 2019)]. It is this domain that is targeted by the cell permeable small molecule inhibitor SMIFH2 (Rizvi et al. 2009). SMIFH2 is soluble in DMSO and in our hands works best when prepared fresh from powder immediately prior to usage. Due to the large number of formins, it might not always be possible to ascertain which formins are active in your tissue of interest a priori. In this context, it might be worthwhile testing the effect of SMIFH2 to determine if formins play a role in the process of interest, followed by more intensive identification and manipulation of the specific formins involved. However, it should be noted that concentrations greater than $5 \mu \mathrm{M}$ for long time periods such as $4 \mathrm{~h}$ have strong toxic effects on various organ systems in zebrafish larvae (LeCorgne et al. 2018).

\section{Lipids}

The membrane is known to exert a profound effect on the actin cytoskeleton (Saarikangas et al. 2010). These effects are either on account of the effects of the membrane on actin-binding proteins or by directly affecting actin filaments by changing properties of the actin membrane interaction (Vasanji et al. 2004; Yin and Janmey 2003). This review will briefly touch upon 3 lipids, namely phosphotidylinositol (PI)-4,5-biphosphate (PIP2), phosphotidylinositol-3,4,5triphosphate (PIP3) and cholesterol.

Cholesterol regulates the physical properties of the membrane, with higher levels leading to less fluid membranes with altered stiffness (Cooper 1978; Ayee and Levitan 2016). It has been shown that the ability of actin to deform membranes requires intermediate levels of cholesterol with levels too high or too low reducing the ability of actin to deform the membrane (Vasanji et al. 2004). Cholesterol is also enriched to appropriate levels in locations that are actin rich such as the leading edge of migrating cells that have lamellipodia or the apical surface of MDCK cells that have microvilli (Vasanji et al. 2004; Gerl et al. 2012).

Filipin is used as a common dye for the imaging of cholesterol in cells. It is sensitive to bleaching and so should be imaged as soon as possible once staining is complete (Boutte et al. 2011). The levels of cholesterols can be decreased by incubating larvae with methyl- $\beta$-cyclodextrin. Methyl- $\beta$ cyclodextrin is water soluble which makes its use in fish media straightforward. It is preferred to make up the solution freshly before use with a good starting working concentration being $2.5 \mathrm{mM}$ for $30 \mathrm{~min}$, concentrations of $10 \mathrm{mM}$ for acute treatments and $0.5 \mathrm{mM}$ for long-term treatments have also been used (Maerz et al. 2019). Methyl- $\beta$-cyclodextrin can also be saturated with cholesterol to make it a cholesterol donor that will increase the levels of cholesterol in cells (Zidovetzki and Levitan 2007).

PIP2 regulates several aspects of actin polymerisation and actin-binding protein activity. PIP2 plays a role in activating WASP proteins that act as nucleation promoting factors for the Arp2/3 complex as well as Ezrin that act as actin membrane linkers (Higgs and Pollard 2000; Jayasundar et al. 2012). PIP 2 can also inhibit the F-actin severing activity of gelsolin (Janmey and Stossel 1987). Apart from these, it can regulate a whole host of actin-binding proteins (Yin and Janmey 2003). PIP2 can be imaged by means of a sensor PLC $81-\mathrm{PH}$ which is the PH domain of phospholipase C81 domain, fused to a fluorescent protein (Yin and Janmey 2003; Watt et al. 2002). This sensor can be genetically encoded and has been used in zebrafish (Gong et al. 2017). It should be noted that this sensor has a preference for PIP2 and will be enriched in PIP2 rich domains, but not normally completely absent from other parts of the plasma membrane.

PIP3 can regulate the RhoGTPases such as Rac that stimulates the polymerisation of actin (Innocenti et al. 2003). PIP3 is synthesized by PI3Kinase and the PH domain of the Akt protein binds to it (Yin and Janmey 2003). Akt-PHGFP can thus be used as a sensor of PIP3 levels in the same way as PLC81-PH for PIP2 and has been used in zebrafish (Yoo et al. 2010). Both PIP2 and PIP3 can be added exogenously to cells (Strawbridge and Elmendorf 2005; MartinBelmonte et al. 2007; Gassama-Diagne et al. 2006), though this method might be difficult when studying internal tissues in zebrafish, for such cases, it might be possible to genetically alter the levels and/or activity of PIP2 or PIP3 synthesizing enzymes.

\section{Genetic tools to study actin biology}

\section{Rho GTPase}

Rho GTPases are a family of small GTPases that have wide ranging effects on the actin cytoskeleton and are important 
regulators of the actin cytoskeleton. Historically, by means of classic experiments from the Hall lab, we know that the three major classes of Rho GTPases have divergent roles (Ridley and Hall 1992; Ridley et al. 1992; Nobes and Hall 1995). Rho GTPases undergo a GTPase cycle with the GTP bound form being active, and the GDP bound form being inactive (Etienne-Manneville and Hall 2002). The Rho GTPases in the active state can interact with a wide variety of effectors for instance Rho GTPase interacts with mDiaphanous (Schwartz 2004). Due to this, the localisation of active Rho GTPase forms inside cells is of interest.

Fluorescence/Förster resonance energy transfer (FRET)based sensor tools that identify the active state of Rho GTPases have been developed and reveal the localisation of active Rho GTPases (Hodgson et al. 2010). These have been used in zebrafish, in various contexts such as their role in the migration of primordial germ cells in developing zebrafish (Kardash et al. 2010).

Apart from observing the in vivo activity of Rho GTPases in cells, manipulating their activity is also possible by means of dominant negative and constitutively active forms of the Rho GTPases (Kardash et al. 2010). Photoactivable forms of the Rac GTPase have also been used providing fine spatiotemporal control over Rac activity (Yoo et al. 2010).

\section{Myosin 2}

Non-muscle myosin IIs (NMMII) have several roles inside the cell with respect to actin. They are involved in actin contraction, crosslinking as well as disassembly of actin (Sonal et al. 2018; Laevsky and Knecht 2003). These acto-myosin interactions play a major role in generating cellular and tissue level forces (Heisenberg and Bellaiche 2013). Consequently, manipulation of the acto-myosin interaction is an important tool in the hands of cell biologist that study the actin cytoskeleton. This manipulation can be by means of drugs such as blebbistatin as well as genetic tools.

NMMIIs are known to be regulated by phosphorylation of their regulatory light chain (Watanabe et al. 2007), with phyosphorylation by the myosin light chain kinase or Rhokinase leading to activation (Heissler and Manstein 2013). Constitutively active forms of the myosin light chain kinase have been used widely to activate myosin and increase actomyosin contractility inside cells (Blaser et al. 2006). NMMII can also be regulated indirectly by regulating Rho GTPase and Rho-kinase. The phosphorylation state of NMMII can also be monitored in cells using FRET based sensors similar to those used in C. elegans (Markwardt et al. 2018).

\section{Arp2/3 complex}

The Arp $2 / 3$ complex is a weak nucleator of actin (Goode et al. 2001). Its nucleation activity is greatly enhanced on activation by nucleation promoting factors such as WASP (Rohatgi et al. 1999). The VCA domain of WASP can activate the Arp2/3 complex, and can be used as a tool to increase its activity in vivo (Rohatgi et al. 1999). On the other hand, the protein Arpin is an inhibitor of the Arp2/3 complex and has been used as a tool to decrease its activity in zebrafish (Dang et al. 2013).

\section{Actin depolymerising agents}

Recently, novel genetically encoded tools that lead to the breakdown of actin have been generated. They have been christened 'DeActs' and consist of parts of proteins such as gelsolin coupled to GFP for visualisation. They have been used and shown to be functional in vivo in mouse and $C$. elegans (Harterink et al. 2017). The F actin network can also be remodelled by genetically modified cofilins that are fused to light activated domains. Such approaches would further enhance the genetic toolkit of actin regulators in zebrafish (Hughes and Lawrence 2014; Stone et al. 2019).

\section{Mutants}

Mutants for a few actin-binding proteins and actins such as Cofilin, capping protein $\beta$-subunit, L-plastin, WASP and skeletal $\alpha$-actin exist and several morpholinos such as that against zDia2 have been used in the past (Kell et al. 2018; Amsterdam et al. 2004; Cvejic et al. 2008; Sztal et al. 2018; Lai et al. 2008). It should be noted that with advances in genome editing as well as transgenesis, it is now possible to make mutants as well as transgenic lines of almost any gene of interest in zebrafish.

\section{Actin model systems}

The rapid development of zebrafish organ systems within a few days of development allows the study of actin in specific contexts and can provide insight into different aspects of actin regulation in specific cell types and tissue. These include the study of migration of neurons, collective migration such as that by the lateral line primordia as well as single cell migration of germ or immune cells, and the development of various muscles (Deng and Huttenlocher 2012; Olson and Nechiporuk 2018; Paksa and Raz 2015; Rocha et al. 2020; Sanger et al. 2009). Here, we discuss examples of a few selected model cell types and tissues in zebrafish, in which actin regulation can be studied in-depth.

\section{Microridges}

Nowhere is the benefit of studying actin in zebrafish more apparent than in the case of the actin microridge. The actin microridge is a widely distributed, labyrinthine actin based 
apical membrane protrusion (Depasquale 2018). It is found on non-keratinising stratified epithelia such as that of the oral or vaginal mucosa (Eroschenko and Osman 1986; Uehara et al. 1991; Saito and Itoh 1993; Depasquale 2018). Likely owing to its internal nature and non-obvious or noncritical function in mammals, it has not been widely studied. However, in the fish and frog systems, the microridge is an epidermal structure and is present on the outermost surface of the animal apart from various internal tissues (Hawkes 1974; Schliwa 1975; Bereiter-Hahn et al. 1979). While most studies on fish from the 1970s to the 1990s focussed on carp, guppy or seahorse, more recently with the advent of zebrafish as a model system, there has been an increased interest in the zebrafish model from a microridge context (Hawkes 1974; Schliwa 1975; Bereiter-Hahn et al. 1979; Uehara et al. 1991; Sharma et al. 2005; Lam et al. 2015; Raman et al. 2016; Pinto et al. 2019; van Loon et al. 2020; Inaba et al. 2020).

The actin microridge in zebrafish offers the benefits of genetic tractability, ease of imaging as well as the easy access of the surface structure to chemical or physical perturbations (Lam et al. 2015; Raman et al. 2016). Consequently, the zebrafish system has provided considerable novel insight to the microridge structure and function. It has been proven using the inhibitors of the Arp2/3 complex as well as immunolocalisation that the microridge is an Arp2/3 dependent structure (Lam et al. 2015; Pinto et al. 2019). Using electron tomography and SEM of detergent extracted samples, it was shown that the zebrafish peridermal actin microridge is a branched actin structure with an actin and keratin terminal web (Pinto et al. 2019). The mechanisms of pattern generation via cytoskeletal contractility, myosin activity and the balance and interplay between the actin and keratin cytoskeletons in the microridge have also been demonstrated with various live imaging techniques using probes such as LifeAct as well as laser ablation, inhibitor studies as well as CA-MLCK (van Loon et al. 2020; Raman et al. 2016; Inaba et al. 2020). Apart from direct studies of the actin cytoskeleton in microridges, the effect that cell polarity regulators have on the actin cytoskeleton have also been demonstrated using the zebrafish peridermal actin microridge system(Raman et al. 2016).

Given the fact that actin microridges are Arp $2 / 3$ dependent structures they can serve an as excellent new model system to study branched actin networks as well as the crosstalk between other pathways such as cell polarity pathways or other cytoskeletal elements and the actin cytoskeleton in vivo.

\section{Microvilli}

Microvilli are cylindrical actin protrusions that are found in several cell types, most notably forming the brush border of intestinal enterocytes (Crawley et al. 2014a). They are thought to increase surface for absorption of nutrients, as well as serve as a reservoir of actin and membrane for wound healing (Ubelmann et al. 2013; Crawley et al. 2014a). The mouse microvillar system has served to study the functions of various actin bundling proteins in vivo especially, fimbrin/plastin, villin and espin as well as myosin 1 and ezrin in actin membrane crosslinking (Revenu et al. 2012; Tyska et al. 2005; Saotome et al. 2004). More recently, the mechanisms that generate microvilli of uniform length have been revealed and are a consequence of inter-microvillar coupling by proto-cadherins (Crawley et al. 2014b).

The zebrafish intestine is functionally homologous to that of mammals (Brugman 2016). It possesses a visually similar brush border to that of the mouse, with densely packed microvilli above a terminal web. However, till date, this structure has not been studied for its actin regulation, though using forward genetic screens some mutants such as slimjim were identified that show a reduced number of microvilli (Pack et al. 1996). The zebrafish goosepimples (Myosin $\mathrm{Vb}$ ) mutant has reduced microvillar length, and microvilli inside internal inclusions (Sidhaye et al. 2016). This was shown using dissection and staining of the larval intestine post fixation, cryo-sectioning, and confocal imaging, as well as standard electron microscopy. This is reminiscent of human microvillus inclusion disease (MVID) and is similar to the various MVID mouse models (Schneeberger et al. 2015; Carton-Garcia et al. 2015; Weis et al. 2016; Ameen and Salas 2000). This further reflects the homology between the mammalian and the zebrafish enterocyte and brush border systems. Such zebrafish models not only have the ability to delineate actin biology but also the pathophysiology of disease. Live imaging in the mammalian intestine is difficult, on the other hand, especially in combination with light sheet microscopy and the transparent nature of albino mutant transgenic models, mechanisms by which changes to the actin cytoskeleton occur will become obvious.

Apart from the intestine, the pronephros is one of the other sites where microvilli are found. Here, it has been shown that the actin-binding peptide Peptidylglycine $\alpha$-amidating monooxygenase (PAM), is necessary for the formation of normal microvilli (Kumar et al. 2018). Similarly, while modified microvilli called 'stereocilia' are found in the inner ear in mouse models, rendering imaging difficult in these systems, in zebrafish, stereocilia are found on the outer surface, as part of the lateral line sense organ as well as the ear or otic vesicle. These structures can be imaged relatively easily and can serve as a suitable model for studying actin biology (Hwang et al. 2015; Chitnis et al. 2012). 


\section{Early development}

A process that requires actin during the earliest stages postfertilization is the segregation of ooplasm from the yolk to the nascent animal pole by means of streaming. It has been recently shown that the fertilized zebrafish oocyte experiences waves of actin polymerisation from the animal to the vegetal pole, and this gradient results in actin flows towards the animal pole that drive the streaming of ooplasm towards this end. The yolk granules are kept at the vegetal pole by means of another actin-based mechanism which is the formation of actin comet-like structures (Shamipour et al. 2019). Actin dynamics has been studied in oocytes and early embryos using a Moesin-GFP fusion (Nukada et al. 2015). Germ plasm segregation and localisation of many maternal RNAs in the early embryo have been found to be actin-dependent (Eno and Pelegri 2018; Theusch et al. 2006; Eno et al. 2019; Nair et al. 2013). Imaging actin dynamics in real time during germ plasm segregation and maternal RNA localisation can provide new insights.

Another prominent actin system during development is the actin ring found during epiboly. A circumferential actomyosin ring forms near the margin of the yolk and enveloping layer, and is present within the yolk cell (Schwayer et al. 2016). Cytochalasin B-treated embryos showed a failure of epiboly suggesting that actin plays a key role in driving epiboly movements (Cheng et al. 2004). The formin zDia2 and Profilin1a proteins appear to play a role in forming this ring downstream of RhoGTPase (Lai et al. 2008). The ring is under tension and apart from circumferential contraction its flow-friction motor activity can drive epiboly (Behrndt et al. 2012). These findings were obtained by live imaging of Utrophin- $\mathrm{CH}$ domain transgenic animals, the use of drugs such as Cytochalasins and jasplakinolide, as well as laser ablation and theory, among other more specialised techniques.

\section{Conclusions}

Though a wide variety of tools to image and modulate actin in vivo and in fixed samples exist, many of them have not yet found widespread usage in the zebrafish model system.

Despite zebrafish being a major model organism for several decades now and despite path breaking work with regards to the cytoskeleton, physical forces and development being performed in fish, detailed analysis of the zebrafish fish actins and their biochemical properties has not yet been performed. This might be due in part to conventional difficulties in purifying actin from native sources and also the fact that zebrafish have been widely used for its strength in genetics and not biochemistry. Nonetheless with the advent of pick-ya actin, one hopes that pure zebrafish actins will soon be purified and their properties studied. In particular, how the $\mathrm{N}$-terminal modifications alter biochemical properties and interactions with actin binding proteins relative to mammalian actins will enhance our understanding of the $\mathrm{N}$-terminus of actins in general.

The zebrafish has significant advantages compared to other vertebrate models when it comes to imaging. This is of benefit when studying the different model systems for actin biology, such as actin microridges. These benefits should be exploited to obtain new insight into the mechanisms by which branched actin structures are formed, how the size of actin based protrusions are controlled as well as how different cytoskeletal filaments co-ordinate their activities. Additionally, the ease of chemical genetics in zebrafish makes the screening of large molecular libraries for phenotypes in actin structures a possibility (Kaufman et al. 2009). Since actin structures such as the microridge have not been fully exploited, forward genetic screens to look at phenotypes of the microridge might reveal new interactors and regulators of the actin cytoskeleton. Finally, newer tools such as single cell RNAseq and proteomics also hold great promise in enabling a more detailed understanding of the actin cytoskeleton.

In the year 2020, actin in the zebrafish has remained relatively untouched and the field is ripe with exciting opportunities and low hanging fruit. We anticipate that in the following decades the humble zebrafish will revolutionise the actin biology field.

Acknowledgements CSP is supported by a BBSRC project grant BB/ S003789/1 to Mohan Balasubramanian, MM and KS. MM is supported by the BBSRC and Warwick Medical School; KS is supported by the BBSRC, Leverhulme Trust and Warwick Medical School.

Open Access This article is licensed under a Creative Commons Attribution 4.0 International License, which permits use, sharing, adaptation, distribution and reproduction in any medium or format, as long as you give appropriate credit to the original author(s) and the source, provide a link to the Creative Commons licence, and indicate if changes were made. The images or other third party material in this article are included in the article's Creative Commons licence, unless indicated otherwise in a credit line to the material. If material is not included in the article's Creative Commons licence and your intended use is not permitted by statutory regulation or exceeds the permitted use, you will need to obtain permission directly from the copyright holder. To view a copy of this licence, visit http://creativecommons.org/licenses/by/4.0/.

\section{References}

Ameen NA, Salas PJ (2000) Microvillus inclusion disease: a genetic defect affecting apical membrane protein traffic in intestinal epithelium. Traffic 1(1):76-83. https://doi.org/10.103 4/j.1600-0854.2000.010111.x

Amsterdam A, Nissen RM, Sun Z, Swindell EC, Farrington S, Hopkins $\mathrm{N}$ (2004) Identification of 315 genes essential for early zebrafish 
development. Proc Natl Acad Sci USA 101(35):12792-12797. https://doi.org/10.1073/pnas.0403929101

Ayee MA, Levitan I (2016) Paradoxical impact of cholesterol on lipid packing and cell stiffness. Front Biosci (Landmark Ed) 21:12451259. https://doi.org/10.2741/4454

Behrndt M, Salbreux G, Campinho P, Hauschild R, Oswald F, Roensch J, Grill SW, Heisenberg CP (2012) Forces driving epithelial spreading in zebrafish gastrulation. Science 338(6104):257-260. https://doi.org/10.1126/science. 1224143

Bereiter-Hahn J, Osborn M, Weber K, Vöth M (1979) Filament organization and formation of microridges at the surface of fish epidermis. J Ultrastruct Res 69(3):316-330. https://doi.org/10.1016/ S0022-5320(79)80050-7

Blaser H, Reichman-Fried M, Castanon I, Dumstrei K, Marlow FL, Kawakami K, Solnica-Krezel L, Heisenberg CP, Raz E (2006) Migration of zebrafish primordial germ cells: a role for myosin contraction and cytoplasmic flow. Dev Cell 11(5):613-627. https ://doi.org/10.1016/j.devcel.2006.09.023

Boutte Y, Men S, Grebe M (2011) Fluorescent in situ visualization of sterols in Arabidopsis roots. Nat Protoc 6(4):446-456. https:// doi.org/10.1038/nprot.2011.323

Breitsprecher D, Goode BL (2013) Formins at a glance. J Cell Sci 126(Pt 1):1-7. https://doi.org/10.1242/jcs.107250

Brown SS, Spudich JA (1981) Mechanism of action of cytochalasin: evidence that it binds to actin filament ends. J Cell Biol 88(3):487-491. https://doi.org/10.1083/jcb.88.3.487

Brown NP, Leroy C, Sander C (1998) MView: a web-compatible database search or multiple alignment viewer. Bioinformatics 14(4):380-381. https://doi.org/10.1093/bioinformatics/14.4.380

Brugman S (2016) The zebrafish as a model to study intestinal inflammation. Dev Comp Immunol 64:82-92. https://doi.org/10.1016/j. dci.2016.02.020

Burkel BM, von Dassow G, Bement WM (2007) Versatile fluorescent probes for actin filaments based on the actin-binding domain of utrophin. Cell Motil Cytoskelet 64(11):822-832. https://doi. org $/ 10.1002 / \mathrm{cm} .20226$

Carton-Garcia F, Overeem AW, Nieto R, Bazzocco S, Dopeso H, Macaya I, Bilic J, Landolfi S, Hernandez-Losa J, Schwartz S Jr, Ramon y Cajal S, van Ijzendoorn SC, Arango D (2015) Myo5b knockout mice as a model of microvillus inclusion disease. Sci Rep 5:12312. https://doi.org/10.1038/srep12312

Cheng JC, Miller AL, Webb SE (2004) Organization and function of microfilaments during late epiboly in zebrafish embryos. Dev Dyn 231(2):313-323. https://doi.org/10.1002/dvdy.20144

Chitnis AB, Nogare DD, Matsuda M (2012) Building the posterior lateral line system in zebrafish. Dev Neurobiol 72(3):234-255. https://doi.org/10.1002/dneu.20962

Coluccio LM, Tilney LG (1984) Phalloidin enhances actin assembly by preventing monomer dissociation. J Cell Biol 99(2):529-535. https://doi.org/10.1083/jcb.99.2.529

Cooper RA (1978) Influence of increased membrane cholesterol on membrane fluidity and cell function in human red blood cells. $\mathbf{J}$ Supramol Struct 8(4):413-430. https://doi.org/10.1002/jss.40008 0404

Crawley SW, Mooseker MS, Tyska MJ (2014a) Shaping the intestinal brush border. J Cell Biol 207(4):441-451. https://doi. org/10.1083/jcb.201407015

Crawley SW, Shifrin DA Jr, Grega-Larson NE, McConnell RE, Benesh AE, Mao S, Zheng Y, Zheng QY, Nam KT, Millis BA, Kachar B, Tyska MJ (2014b) Intestinal brush border assembly driven by protocadherin-based intermicrovillar adhesion. Cell 157(2):433446. https://doi.org/10.1016/j.cell.2014.01.067

Cvejic A, Hall C, Bak-Maier M, Flores MV, Crosier P, Redd MJ, Martin P (2008) Analysis of WASp function during the wound inflammatory response-live-imaging studies in zebrafish larvae. J Cell Sci 121(Pt 19):3196-3206. https://doi.org/10.1242/ jcs.032235

Dang I, Gorelik R, Sousa-Blin C, Derivery E, Guerin C, Linkner J, Nemethova M, Dumortier JG, Giger FA, Chipysheva TA, Ermilova VD, Vacher S, Campanacci V, Herrada I, Planson AG, Fetics S, Henriot V, David V, Oguievetskaia K, Lakisic G, Pierre F, Steffen A, Boyreau A, Peyrieras N, Rottner K, Zinn-Justin S, Cherfils J, Bieche I, Alexandrova AY, David NB, Small JV, Faix J, Blanchoin L, Gautreau A (2013) Inhibitory signalling to the Arp2/3 complex steers cell migration. Nature 503(7475):281284. https://doi.org/10.1038/nature12611

Deng Q, Huttenlocher A (2012) Leukocyte migration from a fish eye's view. J Cell Sci 125(Pt 17):3949-3956. https://doi.org/10.1242/ jcs.093633

Depasquale JA (2018) Actin microridges. Anat Rec (Hoboken) 301(12):2037-2050. https://doi.org/10.1002/ar.23965

dos Remedios CG, Chhabra D, Kekic M, Dedova IV, Tsubakihara M, Berry DA, Nosworthy NJ (2003) Actin binding proteins: regulation of cytoskeletal microfilaments. Physiol Rev 83(2):433-473. https://doi.org/10.1152/physrev.00026.2002

Dutta A, Kumar Sinha D (2015) Turnover of the actomyosin complex in zebrafish embryos directs geometric remodelling and the recruitment of lipid droplets. Sci Rep 5:13915. https://doi. org/10.1038/srep13915

Eno C, Pelegri F (2018) Modulation of F-actin dynamics by maternal Mid1ip1L controls germ plasm aggregation and furrow recruitment in the zebrafish embryo. Development. https://doi. org/10.1242/dev.156596

Eno C, Hansen CL, Pelegri F (2019) Aggregation, segregation, and dispersal of homotypic germ plasm RNPs in the early zebrafish embryo. Dev Dyn 248(4):306-318. https://doi.org/10.1002/ dvdy. 18

Eroschenko VP, Osman F (1986) Scanning electron microscopic changes in vaginal epithelium of suckling neonatal mice in response to estradiol or insecticide chlordecone (Kepone) passage in milk. Toxicology 38(2):175-185. https://doi. org/10.1016/0300-483X(86)90118-6

Etienne-Manneville S, Hall A (2002) Rho GTPases in cell biology. Nature 420(6916):629-635. https://doi.org/10.1038/nature01148

Flores LR, Keeling MC, Zhang X, Sliogeryte K, Gavara N (2019) Author correction: Lifeact-TagGFP2 alters F-actin organization, cellular morphology and biophysical behaviour. Sci Rep 9(1):9507. https://doi.org/10.1038/s41598-019-45276-y

Fujiwara I, Zweifel ME, Courtemanche N, Pollard TD (2018) Latrunculin A accelerates actin filament depolymerization in addition to sequestering actin monomers. Curr Biol 28(19):31833192e3182. https://doi.org/10.1016/j.cub.2018.07.082

Galletta BJ, Chuang DY, Cooper JA (2008) Distinct roles for Arp2/3 regulators in actin assembly and endocytosis. PLoS Biol 6(1):e1. https://doi.org/10.1371/journal.pbio.0060001

Gassama-Diagne A, Yu W, ter Beest M, Martin-Belmonte F, Kierbel A, Engel J, Mostov K (2006) Phosphatidylinositol-3,4,5trisphosphate regulates the formation of the basolateral plasma membrane in epithelial cells. Nat Cell Biol 8(9):963-970. https ://doi.org/10.1038/ncb1461

Gerl MJ, Sampaio JL, Urban S, Kalvodova L, Verbavatz JM, Binnington B, Lindemann D, Lingwood CA, Shevchenko A, Schroeder C, Simons K (2012) Quantitative analysis of the lipidomes of the influenza virus envelope and MDCK cell apical membrane. J Cell Biol 196(2):213-221. https://doi.org/10.1083/jcb.201108175

Gong B, Shen W, Xiao W, Meng Y, Meng A, Jia S (2017) The Sec14like phosphatidylinositol transfer proteins Sec1413/SEC14L2 act as GTPase proteins to mediate $\mathrm{Wnt} / \mathrm{Ca}(2+)$ signaling. eLife. https://doi.org/10.7554/eLife.26362 
Goode BL, Rodal AA, Barnes G, Drubin DG (2001) Activation of the Arp $2 / 3$ complex by the actin filament binding protein Abp1p. J Cell Biol 153(3):627-634. https://doi.org/10.1083/jcb.153.3.627

Gupta K, Sonawane M (2020) CMV promoter-driven expression and visualization of tagged proteins in live and fixed zebrafish embryonic epidermis. In: Gupta N, Gupta V (eds) Experimental protocols in biotechnology. Springer US, New York, pp 29-41. https ://doi.org/10.1007/978-1-0716-0607-0_3

Harterink M, da Silva ME, Will L, Turan J, Ibrahim A, Lang AE, van Battum EY, Pasterkamp RJ, Kapitein LC, Kudryashov D, Barres BA, Hoogenraad CC, Zuchero JB (2017) DeActs: genetically encoded tools for perturbing the actin cytoskeleton in single cells. Nat Methods 14(5):479-482. https://doi.org/10.1038/ nmeth. 4257

Hatano T, Alioto S, Roscioli E, Palani S, Clarke ST, Kamnev A, Hernandez-Fernaud JR, Sivashanmugam L, Chapa YLB, Jones AME, Robinson RC, Sampath K, Mishima M, McAinsh AD, Goode BL, Balasubramanian MK (2018) Rapid production of pure recombinant actin isoforms in Pichia pastoris. J Cell Sci. https://doi.org/10.1242/jcs.213827

Hatano T, Sivashanmugam L, Suchenko A, Hussain H, Balasubramanian MK (2020) Pick-ya actin—a method to purify actin isoforms with bespoke key post-translational modifications. J Cell Sci. https://doi.org/10.1242/jcs.241406

Hawkes JW (1974) The structure of fish skin. Cell Tissue Res 149(2):147-158. https://doi.org/10.1007/BF00222270

Heisenberg CP, Bellaiche Y (2013) Forces in tissue morphogenesis and patterning. Cell 153(5):948-962. https://doi.org/10.1016/j. cell.2013.05.008

Heissler SM, Manstein DJ (2013) Nonmuscle myosin-2: mix and match. Cell Mol Life Sci 70(1):1-21. https://doi.org/10.1007/ s00018-012-1002-9

Hetrick B, Han MS, Helgeson LA, Nolen BJ (2013) Small molecules CK-666 and CK-869 inhibit actin-related protein 2/3 complex by blocking an activating conformational change. Chem Biol 20(5):701-712. https://doi.org/10.1016/j.chembiol.2013.03.019

Heuser JE, Kirschner MW (1980) Filament organization revealed in platinum replicas of freeze-dried cytoskeletons. J Cell Biol 86(1):212-234. https://doi.org/10.1083/jcb.86.1.212

Higgs HN, Pollard TD (2000) Activation by Cdc42 and PIP(2) of Wiskott-Aldrich syndrome protein (WASp) stimulates actin nucleation by Arp2/3 complex. J Cell Biol 150(6):1311-1320. https://doi.org/10.1083/jcb.150.6.1311

Hodgson L, Shen F, Hahn K (2010) Biosensors for characterizing the dynamics of rho family GTPases in living cells. Curr Protoc Cell Biol Chapter 14:Unit 1411 11-26. https://doi.org/10.1002/04711 43030.cb1411s46

Hughes RM, Lawrence DS (2014) Optogenetic engineering: lightdirected cell motility. Angew Chem Int Ed Engl 53(41):1090410907. https://doi.org/10.1002/anie.201404198

Hwang P, Chou SW, Chen Z, McDermott BM Jr (2015) The stereociliary paracrystal is a dynamic cytoskeletal scaffold in vivo. Cell Rep 13(7):1287-1294. https://doi.org/10.1016/j.celre p.2015.10.003

Inaba Y, Chauhan V, van Loon AP, Choudhury LS, Sagasti A (2020) Keratins and Plakin family cytolinker proteins control the length of epithelial microridge protrusions. eLife 9:e58149. https://doi. org/10.7554/eLife.58149

Innocenti M, Frittoli E, Ponzanelli I, Falck JR, Brachmann SM, Di Fiore PP, Scita G (2003) Phosphoinositide 3-kinase activates Rac by entering in a complex with Eps8, Abi1, and Sos-1. J Cell Biol 160(1):17-23. https://doi.org/10.1083/jcb.200206079

Janmey PA, Stossel TP (1987) Modulation of gelsolin function by phosphatidylinositol 4,5-bisphosphate. Nature 325(6102):362364. https://doi.org/10.1038/325362a0
Jayasundar JJ, Ju JH, He L, Liu D, Meilleur F, Zhao J, Callaway DJ, Bu Z (2012) Open conformation of ezrin bound to phosphatidylinositol 4,5-bisphosphate and to F-actin revealed by neutron scattering. J Biol Chem 287(44):37119-37133. https://doi.org/10.1074/ jbc.M112.380972

Kardash E, Reichman-Fried M, Maitre JL, Boldajipour B, Papusheva E, Messerschmidt EM, Heisenberg CP, Raz E (2010) A role for Rho GTPases and cell-cell adhesion in single-cell motility in vivo. Nat Cell Biol 12(1):47-53; sup pp 41-11. https://doi. org/10.1038/ncb2003

Kashina AS (2006) Differential arginylation of actin isoforms: the mystery of the actin N-terminus. Trends Cell Biol 16(12):610-615. https://doi.org/10.1016/j.tcb.2006.10.001

Kaufman CK, White RM, Zon L (2009) Chemical genetic screening in the zebrafish embryo. Nat Protoc 4(10):1422-1432. https://doi. org/10.1038/nprot.2009.144

Kawakami K (2007) Tol2: a versatile gene transfer vector in vertebrates. Genome Biol 8(1):S7. https://doi.org/10.1186/gb-2007-8-s1-s7

Kell MJ, Riccio RE, Baumgartner EA, Compton ZJ, Pecorin PJ, Mitchell TA, Topczewski J, LeClair EE (2018) Targeted deletion of the zebrafish actin-bundling protein L-plastin (lcp1). PLoS One 13(1):e0190353. https://doi.org/10.1371/journ al.pone. 0190353

Korobova F, Svitkina T (2008) Arp2/3 complex is important for filopodia formation, growth cone motility, and neuritogenesis in neuronal cells. Mol Biol Cell 19(4):1561-1574. https://doi. org/10.1091/mbc.E07-09-0964

Kovacs M, Toth J, Hetenyi C, Malnasi-Csizmadia A, Sellers JR (2004) Mechanism of blebbistatin inhibition of myosin II. J Biol Chem 279(34):35557-35563. https://doi.org/10.1074/jbc.M405319200

Kumar D, Thomason RT, Yankova M, Gitlin JD, Mains RE, Eipper BA, King SM (2018) Microvillar and ciliary defects in zebrafish lacking an actin-binding bioactive peptide amidating enzyme. Sci Rep 8(1):4547. https://doi.org/10.1038/s41598-018-22732-9

Laevsky G, Knecht DA (2003) Cross-linking of actin filaments by myosin II is a major contributor to cortical integrity and cell motility in restrictive environments. J Cell Sci 116(Pt 18):3761-3770. https://doi.org/10.1242/jcs.00684

Lai SL, Chan TH, Lin MJ, Huang WP, Lou SW, Lee SJ (2008) Diaphanous-related formin 2 and profilin I are required for gastrulation cell movements. PLoS One 3(10):e3439. https://doi.org/10.1371/ journal.pone.0003439

Lam PY, Mangos S, Green JM, Reiser J, Huttenlocher A (2015) In vivo imaging and characterization of actin microridges. PLoS One 10(1):e0115639. https://doi.org/10.1371/journal.pone.0115639

Latorre E, Kale S, Casares L, Gomez-Gonzalez M, Uroz M, Valon L, Nair RV, Garreta E, Montserrat N, Del Campo A, Ladoux B, Arroyo M, Trepat X (2018) Active superelasticity in three-dimensional epithelia of controlled shape. Nature 563(7730):203-208. https://doi.org/10.1038/s41586-018-0671-4

LeCorgne H, Tudosie AM, Lavik K, Su R, Becker KN, Moore S, Walia Y, Wisner A, Koehler D, Alberts AS, Williams FE, Eisenmann KM (2018) Differential toxicity of mDia formin-directed functional agonists and antagonists in developing zebrafish. Front Pharmacol 9:340. https://doi.org/10.3389/fphar.2018.00340

Leyton-Puig D, Kedziora KM, Isogai T, van den Broek B, Jalink K, Innocenti M (2016) PFA fixation enables artifact-free super-resolution imaging of the actin cytoskeleton and associated proteins. Biol Open 5(7):1001. https://doi.org/10.1242/bio.019570

Lukinavicius G, Umezawa K, Olivier N, Honigmann A, Yang G, Plass T, Mueller V, Reymond L, Correa IR Jr, Luo ZG, Schultz C, Lemke EA, Heppenstall P, Eggeling C, Manley S, Johnsson K (2013) A near-infrared fluorophore for live-cell super-resolution microscopy of cellular proteins. Nat Chem 5(2):132-139. https ://doi.org/10.1038/nchem.1546 
Lukinavicius G, Reymond L, D’Este E, Masharina A, Gottfert F, Ta H, Guther A, Fournier M, Rizzo S, Waldmann H, Blaukopf C, Sommer C, Gerlich DW, Arndt HD, Hell SW, Johnsson K (2014) Fluorogenic probes for live-cell imaging of the cytoskeleton. Nat Methods 11(7):731-733. https://doi.org/10.1038/nmeth.2972

MacLean-Fletcher S, Pollard TD (1980) Mechanism of action of cytochalasin B on actin. Cell 20(2):329-341. https://doi. org/10.1016/0092-8674(80)90619-4

Maerz LD, Burkhalter MD, Schilpp C, Wittekindt OH, Frick M, Philipp M (2019) Pharmacological cholesterol depletion disturbs ciliogenesis and ciliary function in developing zebrafish. Commun Biol 2:31. https://doi.org/10.1038/s42003-018-0272-7

Markwardt ML, Snell NE, Guo M, Wu Y, Christensen R, Liu H, Shroff H, Rizzo MA (2018) A genetically encoded biosensor strategy for quantifying non-muscle myosin II phosphorylation dynamics in living cells and organisms. Cell Rep 24(4):1060-1070 e1064. https://doi.org/10.1016/j.celrep.2018.06.088

Martin-Belmonte F, Gassama A, Datta A, Yu W, Rescher U, Gerke V, Mostov K (2007) PTEN-mediated apical segregation of phosphoinositides controls epithelial morphogenesis through Cdc42. Cell 128(2):383-397. https://doi.org/10.1016/j. cell.2006.11.051

Matejcic M, Salbreux G, Norden C (2018) A non-cell-autonomous actin redistribution enables isotropic retinal growth. PLoS Biol 16(8):e2006018. https://doi.org/10.1371/journal.pbio.2006018

Melak M, Plessner M, Grosse R (2017) Actin visualization at a glance. J Cell Sci 130(3):525-530. https://doi.org/10.1242/ jcs. 189068

Meyers JR (2018) Zebrafish: development of a vertebrate model organism. Curr Protoc Essent Lab Tech 16(1):e19. https://doi. org/10.1002/cpet.19

Mitchell AL, Attwood TK, Babbitt PC, Blum M, Bork P, Bridge A, Brown SD, Chang HY, El-Gebali S, Fraser MI, Gough J, Haft DR, Huang H, Letunic I, Lopez R, Luciani A, Madeira F, Marchler-Bauer A, Mi H, Natale DA, Necci M, Nuka G, Orengo C, Pandurangan AP, Paysan-Lafosse T, Pesseat S, Potter SC, Qureshi MA, Rawlings ND, Redaschi N, Richardson LJ, Rivoire C, Salazar GA, Sangrador-Vegas A, Sigrist CJA, Sillitoe I, Sutton GG, Thanki N, Thomas PD, Tosatto SCE, Yong SY, Finn RD (2019) InterPro in 2019: improving coverage, classification and access to protein sequence annotations. Nucleic Acids Res 47(D1):D351-D360. https://doi.org/10.1093/nar/gky1100

Nagasaki A, Kijima ST, Yumoto T, Imaizumi M, Yamagishi A, Kim H, Nakamura C, Uyeda TQP (2017) The position of the GFP tag on actin affects the filament formation in mammalian cells. Cell Struct Funct 42(2):131-140. https://doi.org/10.1247/csf.17016

Nair S, Marlow F, Abrams E, Kapp L, Mullins MC, Pelegri F (2013) The chromosomal passenger protein birc $5 \mathrm{~b}$ organizes microfilaments and germ plasm in the zebrafish embryo. PLoS Genet 9(4):e1003448. https://doi.org/10.1371/journal.pgen.1003448

Nobes CD, Hall A (1995) Rho, rac, and cdc42 GTPases regulate the assembly of multimolecular focal complexes associated with actin stress fibers, lamellipodia, and filopodia. Cell 81(1):53-62. https://doi.org/10.1016/0092-8674(95)90370-4

Nolen BJ, Tomasevic N, Russell A, Pierce DW, Jia Z, McCormick CD, Hartman J, Sakowicz R, Pollard TD (2009) Characterization of two classes of small molecule inhibitors of Arp2/3 complex. Nature 460(7258):1031-1034. https://doi.org/10.1038/natur $\mathrm{e} 08231$

Nukada Y, Horie M, Fukui A, Kotani T, Yamashita M (2015) Real-time imaging of actin filaments in the zebrafish oocyte and embryo. Cytoskeleton (Hoboken) 72(9):491-501. https://doi.org/10.1002/ cm. 21253

Olson HM, Nechiporuk AV (2018) Using zebrafish to study collective cell migration in development and disease. Front Cell Dev Biol 6:83. https://doi.org/10.3389/fcell.2018.00083
Pack M, Solnica-Krezel L, Malicki J, Neuhauss SC, Schier AF, Stemple DL, Driever W, Fishman MC (1996) Mutations affecting development of zebrafish digestive organs. Development 123:321-328

Paksa A, Raz E (2015) Zebrafish germ cells: motility and guided migration. Curr Opin Cell Biol 36:80-85. https://doi.org/10.1016/j. ceb.2015.07.007

Panza P, Maier J, Schmees C, Rothbauer U, Sollner C (2015) Live imaging of endogenous protein dynamics in zebrafish using chromobodies. Development 142(10):1879-1884. https://doi. org/10.1242/dev.118943

Pereira PM, Albrecht D, Culley S, Jacobs C, Marsh M, Mercer J, Henriques R (2019) Fix your membrane receptor imaging: actin cytoskeleton and CD4 membrane organization disruption by chemical fixation. Front Immunol 10:675. https://doi. org/10.3389/fimmu.2019.00675

Pinto CS, Khandekar A, Bhavna R, Kiesel P, Pigino G, Sonawane M (2019) Microridges are apical epithelial projections formed of F-actin networks that organize the glycan layer. Sci Rep 9(1):12191. https://doi.org/10.1038/s41598-019-48400-0

Planques V, Warn A, Warn RM (1991) The effects of microinjection of rhodamine-phalloidin on mitosis and cytokinesis in early stage Drosophila embryos. Exp Cell Res 192(2):557-566. https://doi. org/10.1016/0014-4827(91)90076-7

Pollard TD (1986) Rate constants for the reactions of ATP- and ADPactin with the ends of actin filaments. J Cell Biol 103(6 Pt 2):2747-2754. https://doi.org/10.1083/jcb.103.6.2747

Pollard TD, Blanchoin L, Mullins RD (2000) Molecular mechanisms controlling actin filament dynamics in nonmuscle cells. Annu Rev Biophys Biomol Struct 29:545-576. https://doi.org/10.1146/ annurev.biophys.29.1.545

Raman R, Damle I, Rote R, Banerjee S, Dingare C, Sonawane M (2016) aPKC regulates apical localization of $\mathrm{Lgl}$ to restrict elongation of microridges in developing zebrafish epidermis. Nat Commun 7:11643. https://doi.org/10.1038/ncomms11643

Revenu C, Ubelmann F, Hurbain I, El-Marjou F, Dingli F, Loew D, Delacour D, Gilet J, Brot-Laroche E, Rivero F, Louvard D, Robine $S$ (2012) A new role for the architecture of microvillar actin bundles in apical retention of membrane proteins. Mol Biol Cell 23(2):324-336. https://doi.org/10.1091/mbc.E11-09-0765

Ridley AJ, Hall A (1992) The small GTP-binding protein rho regulates the assembly of focal adhesions and actin stress fibers in response to growth factors. Cell 70(3):389-399. https://doi. org/10.1016/0092-8674(92)90163-7

Ridley AJ, Paterson HF, Johnston CL, Diekmann D, Hall A (1992) The small GTP-binding protein rac regulates growth factorinduced membrane ruffling. Cell 70(3):401-410. https://doi. org/10.1016/0092-8674(92)90164-8

Riedl J, Crevenna AH, Kessenbrock K, Yu JH, Neukirchen D, Bista M, Bradke F, Jenne D, Holak TA, Werb Z, Sixt M, WedlichSoldner R (2008) Lifeact: a versatile marker to visualize F-actin. Nat Methods 5(7):605-607. https://doi.org/10.1038/nmeth.1220

Rizvi SA, Neidt EM, Cui J, Feiger Z, Skau CT, Gardel ML, Kozmin SA, Kovar DR (2009) Identification and characterization of a small molecule inhibitor of formin-mediated actin assembly. Chem Biol 16(11):1158-1168. https://doi.org/10.1016/j.chemb iol.2009.10.006

Rocha M, Singh N, Ahsan K, Beiriger A, Prince VE (2020) Neural crest development: insights from the zebrafish. Dev Dyn 249(1):88-111. https://doi.org/10.1002/dvdy.122

Rohatgi R, Ma L, Miki H, Lopez M, Kirchhausen T, Takenawa T, Kirschner MW (1999) The interaction between N-WASP and the Arp2/3 complex links Cdc42-dependent signals to actin assembly. Cell 97(2):221-231. https://doi.org/10.1016/s0092 $-8674(00) 80732-1$ 
Rosen JN, Sweeney MF, Mably JD (2009) Microinjection of zebrafish embryos to analyze gene function. J Vis Exp. https://doi. org/10.3791/1115

Rubenstein PA (1990) The functional importance of multiple actin isoforms. BioEssays 12(7):309-315. https://doi.org/10.1002/ bies. 950120702

Saarikangas J, Zhao H, Lappalainen P (2010) Regulation of the actin cytoskeleton-plasma membrane interplay by phosphoinositides. Physiol Rev 90(1):259-289. https://doi.org/10.1152/physr ev.00036.2009

Saito H, Itoh I (1993) Ultrastructural study of rabbit buccal epithelial cells and intercellular junction by scanning and transmission electron microscopy. J Electron Microsc 42(6):389-393. https:// doi.org/10.1093/oxfordjournals.jmicro.a051058

Sakamoto T, Limouze J, Combs CA, Straight AF, Sellers JR (2005) Blebbistatin, a myosin II inhibitor, is photoinactivated by blue light. Biochemistry 44(2):584-588. https://doi.org/10.1021/bi048 3357

Sanger JW, Wang J, Holloway B, Du A, Sanger JM (2009) Myofibrillogenesis in skeletal muscle cells in zebrafish. Cell Motil Cytoskelet 66(8):556-566. https://doi.org/10.1002/cm.20365

Saotome I, Curto M, McClatchey AI (2004) Ezrin is essential for epithelial organization and villus morphogenesis in the developing intestine. Dev Cell 6(6):855-864. https://doi.org/10.1016/j.devce 1.2004.05.007

Scheid LM, Weber C, Bopp N, Mosqueira M, Fink RHA (2017) Extraction protocols for individual zebrafish's ventricle myosin and skeletal muscle actin for in vitro motility assays. Front Physiol 8:367. https://doi.org/10.3389/fphys.2017.00367

Schliwa M (1975) Cytoarchitecture of surface layer cells of the teleost epidermis. J Ultrastruct Res 52(3):377-386. https://doi. org/10.1016/S0022-5320(75)80076-1

Schneeberger K, Vogel GF, Teunissen H, van Ommen DD, Begthel H, El Bouazzaoui L, van Vugt AH, Beekman JM, Klumperman J, Muller T, Janecke A, Gerner P, Huber LA, Hess MW, Clevers $\mathrm{H}$, van Es JH, Nieuwenhuis EE, Middendorp S (2015) An inducible mouse model for microvillus inclusion disease reveals a role for myosin $\mathrm{Vb}$ in apical and basolateral trafficking. Proc Natl Acad Sci USA 112(40):12408-12413. https://doi.org/10.1073/ pnas. 1516672112

Schonichen A, Geyer M (2010) Fifteen formins for an actin filament: a molecular view on the regulation of human formins. Biochim Biophys Acta 1803(2):152-163. https://doi.org/10.1016/j.bbamc r.2010.01.014

Schwartz M (2004) Rho signalling at a glance. J Cell Sci $117(\mathrm{Pt}$ 23):5457-5458. https://doi.org/10.1242/jcs.01582

Schwayer C, Sikora M, Slovakova J, Kardos R, Heisenberg CP (2016) Actin rings of power. Dev Cell 37(6):493-506. https://doi. org/10.1016/j.devcel.2016.05.024

Shamipour S, Kardos R, Xue SL, Hof B, Hannezo E, Heisenberg CP (2019) Bulk actin dynamics drive phase segregation in zebrafish oocytes. Cell 177(6):1463-1479 e1418. https://doi.org/10.1016/j. cell.2019.04.030

Sharma A, Anderson KI, Müller DJ (2005) Actin microridges characterized by laser scanning confocal and atomic force microscopy. FEBS Lett 579(9):2001-2008. https://doi.org/10.1016/j.febs1 et.2005.02.049

Sidhaye J, Pinto CS, Dharap S, Jacob T, Bhargava S, Sonawane M (2016) The zebrafish goosepimples/myosin Vb mutant exhibits cellular attributes of human microvillus inclusion disease. Mech Dev 142:62-74. https://doi.org/10.1016/j.mod.2016.08.001

Sievers F, Wilm A, Dineen D, Gibson TJ, Karplus K, Li W, Lopez R, McWilliam H, Remmert M, Söding J, Thompson JD, Higgins DG (2011) Fast, scalable generation of high-quality protein multiple sequence alignments using Clustal Omega. Mol Syst Biol 7(1):539. https://doi.org/10.1038/msb.2011.75

Sonal, Ganzinger KA, Vogel SK, Mücksch J, Blumhardt P, Schwille P (2018) Myosin-II activity generates a dynamic steady state with continuous actin turnover in a minimal actin cortex. J Cell Sci. https://doi.org/10.1242/jcs.219899

Stone OJ, Pankow N, Liu B, Sharma VP, Eddy RJ, Wang H, Putz AT, Teets FD, Kuhlman B, Condeelis JS, Hahn KM (2019) Optogenetic control of cofilin and alphaTAT in living cells using Z-lock. Nat Chem Biol 15(12):1183-1190. https://doi.org/10.1038/s4158 9-019-0405-4

Strawbridge AB, Elmendorf JS (2005) Phosphatidylinositol 4,5-bisphosphate reverses endothelin-1-induced insulin resistance via an actin-dependent mechanism. Diabetes 54(6):1698-1705. https ://doi.org/10.2337/diabetes.54.6.1698

Svitkina T (2016) Imaging cytoskeleton components by electron microscopy. Methods Mol Biol 1365:99-118. https://doi. org/10.1007/978-1-4939-3124-8_5

Svitkina TM, Verkhovsky AB, McQuade KM, Borisy GG (1997) Analysis of the actin-myosin II system in fish epidermal keratocytes: mechanism of cell body translocation. J Cell Biol 139(2):397415. https://doi.org/10.1083/jcb.139.2.397

Sztal TE, McKaige EA, Williams C, Ruparelia AA, Bryson-Richardson RJ (2018) Genetic compensation triggered by actin mutation prevents the muscle damage caused by loss of actin protein. PLoS Genet 14(2):e1007212. https://doi.org/10.1371/journ al.pgen.1007212

Theusch EV, Brown KJ, Pelegri F (2006) Separate pathways of RNA recruitment lead to the compartmentalization of the zebrafish germ plasm. Dev Biol 292(1):129-141. https://doi.org/10.1016/j. ydbio.2005.12.045

Torraca V, Mostowy S (2018) Zebrafish infection: from pathogenesis to cell biology. Trends Cell Biol 28(2):143-156. https://doi. org/10.1016/j.tcb.2017.10.002

Tyska MJ, Mackey AT, Huang JD, Copeland NG, Jenkins NA, Mooseker MS (2005) Myosin-1a is critical for normal brush border structure and composition. Mol Biol Cell 16(5):2443-2457. https://doi.org/10.1091/mbc.e04-12-1116

Ubelmann F, Chamaillard M, El-Marjou F, Simon A, Netter J, Vignjevic D, Nichols BL, Quezada-Calvillo R, Grandjean T, Louvard D, Revenu C, Robine S (2013) Enterocyte loss of polarity and gut wound healing rely upon the F-actin-severing function of villin. Proc Natl Acad Sci 110(15):E1380. https://doi.org/10.1073/ pnas. 1218446110

Uehara K, Miyoshi M, Miyoshi S (1991) Cytoskeleton in microridges of the oral mucosal epithelium in the carp, Cyprinus carpio. Anat Rec 230(2):164-168. https://doi.org/10.1002/ar.1092300203

UniProt Consortium (2019) UniProt: a worldwide hub of protein knowledge. Nucleic Acids Res 47(D1):D506-D515. https://doi. org/10.1093/nar/gky1049

Vacaru AM, Unlu G, Spitzner M, Mione M, Knapik EW, Sadler KC (2014) In vivo cell biology in zebrafish-providing insights into vertebrate development and disease. J Cell Sci 127(Pt 3):485495. https://doi.org/10.1242/jcs. 140194

van Loon AP, Erofeev IS, Maryshev IV, Goryachev AB, Sagasti A (2020) Cortical contraction drives the 3D patterning of epithelial cell surfaces. J Cell Biol. https://doi.org/10.1083/jcb.201904144

Varland S, Vandekerckhove J, Drazic A (2019) Actin post-translational modifications: the Cinderella of cytoskeletal control. Trends Biochem Sci 44(6):502-516. https://doi.org/10.1016/j. tibs.2018.11.010

Vasanji A, Ghosh PK, Graham LM, Eppell SJ, Fox PL (2004) Polarization of plasma membrane microviscosity during endothelial cell migration. Dev Cell 6(1):29-41. https://doi.org/10.1016/s1534 $-5807(03) 00397-6$ 
Wang Y-C, Peterson SE, Loring JF (2014) Protein post-translational modifications and regulation of pluripotency in human stem cells. Cell Res 24(2):143-160. https://doi.org/10.1038/cr.2013.151

Watanabe T, Hosoya H, Yonemura S (2007) Regulation of myosin II dynamics by phosphorylation and dephosphorylation of its light chain in epithelial cells. Mol Biol Cell 18(2):605-616. https:// doi.org/10.1091/mbc.e06-07-0590

Waterman-Storer CM, Desai A, Bulinski JC, Salmon ED (1998) Fluorescent speckle microscopy, a method to visualize the dynamics of protein assemblies in living cells. Curr Biol 8(22):1227-1230. https://doi.org/10.1016/s0960-9822(07)00515-5

Watt SA, Kular G, Fleming IN, Downes CP, Lucocq JM (2002) Subcellular localization of phosphatidylinositol 4,5-bisphosphate using the pleckstrin homology domain of phospholipase $\mathrm{C}$ delta1. Biochem J 363(Pt 3):657-666. https://doi.org/10.1042/02646021:3630657

Weis VG, Knowles BC, Choi E, Goldstein AE, Williams JA, Manning EH, Roland JT, Lapierre LA, Goldenring JR (2016) Loss of MYO5B in mice recapitulates Microvillus Inclusion Disease and reveals an apical trafficking pathway distinct to neonatal duodenum. Cell Mol Gastroenterol Hepatol 2(2):131-157. https://doi. org/10.1016/j.jcmgh.2015.11.009

Wheatley SP, Wang Y-1 (1998) Chapter 18 Indirect immunofluorescence microscopy in cultured cells. In: Mather JP, Barnes D (eds) Methods in cell biology, vol 57. Academic Press, Cambridge, pp 313-332. https://doi.org/10.1016/S0091-679X(08)61588-5

Winder SJ, Hemmings L, Maciver SK, Bolton SJ, Tinsley JM, Davies KE, Critchley DR, Kendrick-Jones J (1995) Utrophin actin binding domain: analysis of actin binding and cellular targeting. J Cell Sci 108(Pt 1):63-71

Wu C, Asokan SB, Berginski ME, Haynes EM, Sharpless NE, Griffith JD, Gomez SM, Bear JE (2012) Arp2/3 is critical for lamellipodia and response to extracellular matrix cues but is dispensable for chemotaxis. Cell 148(5):973-987. https://doi.org/10.1016/j. cell.2011.12.034

Wulf E, Deboben A, Bautz FA, Faulstich H, Wieland T (1979) Fluorescent phallotoxin, a tool for the visualization of cellular actin. Proc Natl Acad Sci USA 76(9):4498-4502. https://doi.org/10.1073/ pnas.76.9.4498

Yin HL, Janmey PA (2003) Phosphoinositide regulation of the actin cytoskeleton. Annu Rev Physiol 65:761-789. https://doi. org/10.1146/annurev.physiol.65.092101.142517

Yoo SK, Deng Q, Cavnar PJ, Wu YI, Hahn KM, Huttenlocher A (2010) Differential regulation of protrusion and polarity by PI3K during neutrophil motility in live zebrafish. Dev Cell 18(2):226-236. https://doi.org/10.1016/j.devcel.2009.11.015

Zidovetzki R, Levitan I (2007) Use of cyclodextrins to manipulate plasma membrane cholesterol content: evidence, misconceptions and control strategies. Biochim Biophys Acta 1768(6):13111324. https://doi.org/10.1016/j.bbamem.2007.03.026

Publisher's Note Springer Nature remains neutral with regard to jurisdictional claims in published maps and institutional affiliations. 